\title{
Debris flows and flash floods in the Putih River after the 2010 eruption of Mt. Merapi, Indonesia
}

\author{
Yutaka GONDA ${ }^{1}$, Djoko LEGONO ${ }^{2}$, Bambang SUKATJA ${ }^{3}$, and Untung Budi SANTOSA ${ }^{3}$ \\ ${ }^{1}$ Faculty of Agriculture, Niigata University (Ikarashi 2-no-cho, Nishi-ku, Niigata 950-2181, Japan) \\ E-mail: gonda@agr.niigata-u.ac.jp \\ 2 Civil \& Environmental Engineering Department, Gadjah Mada University (Jl. Grafika No. 2, Yogyakarta 55581, Indonesia) \\ 3 Balai Sabo, Ministry of Public Works (Sopalan, Maguwoharjo, Depok Sleman, Yogyakarta 55282, Indonesia)
}

\begin{abstract}
After the 2010 eruption of Mt. Merapi in Indonesia, many instances of debris flows and flash floods occurred in the Putih River basin. The characteristics of debris flows and flash floods were analyzed using images of these events captured by an internet protocol (IP) camera installed near the PU-C11 sabo dam and rainfall records collected at the Gunung Maron observation station. The magnitude of debris flows and flash floods during the 2011-2012 rainy season was smaller than during the 2010-2011 rainy season. Additionally, the rainfall intensity that caused no debris flows or flash floods during the 2011-2012 rainy season was smaller than that observed during the early 1990s, when few debris flows and flash floods occurred. These results suggest that the hydrological regime of the catchment area was radically altered after the eruption.
\end{abstract}

Keywords: debris flow, flash flood, Mt. Merapi, eruption, Putih River

\section{INTRODUCTION}

Mt. Merapi is one of the most active volcanoes in Indonesia. A large eruption occurred at Mt. Merapi on October 26, 2010. Sixty percent of the 140 million cubic meters of eruption material released by the 2010 eruption was deposited on the west side of the mountain $[B N B P, 2011]$. During the rainy season after the eruption, many debris flows and flash floods occurred, causing serious damage to infrastructure including roads, bridges, and sabo dams. Figure 1 shows the number of days debris flows or flash floods occurred between October 2010 and May 2012. The events were counted based on information gathered from online newspapers and other websites. Among the rivers located on the southern and south-western slopes of Mt. Merapi, the number of debris flows and flash floods was highest in the Putih River [Gonda et al., 2012; De Belizal et al., 2013].

Investigations of debris flows and flash floods after volcanic eruptions can provide essential information to local governments for developing disaster mitigation plans. De Belizal et al. [2013] reported rain-triggered lahars following the 2010 eruption in detail, focusing on its related damages. However, the characteristics of debris flows and flash

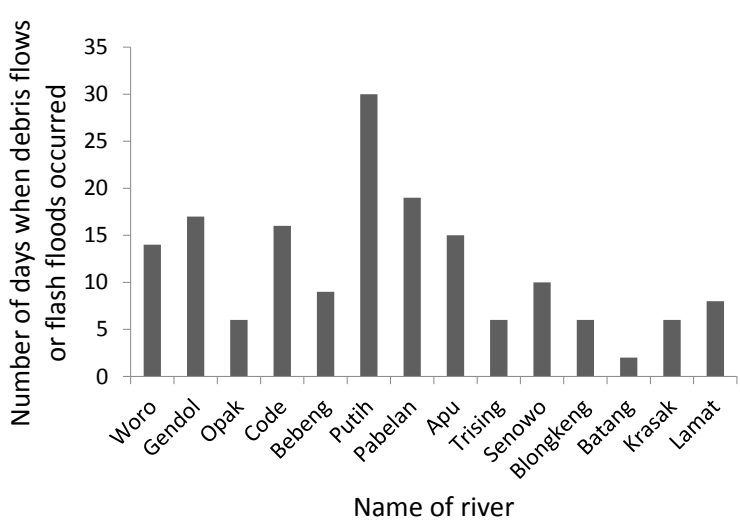

Fig. 1 Number of days when debris flows or flash floods occurred between October 2010 and March 2012 in Indonesia [Gonda et al., 2012].

floods were not investigated fully because most of the monitoring equipment installed around the south and south-western slopes of the volcano was damaged. The damage was likely caused by the high temperatures of the pyroclastic surge and ash fall during the eruption.

In this paper, the characteristics of debris flows and flash floods in the Putih River, where debris flows and flash floods occurred frequently after the eruption, were analyzed using records obtained by an 


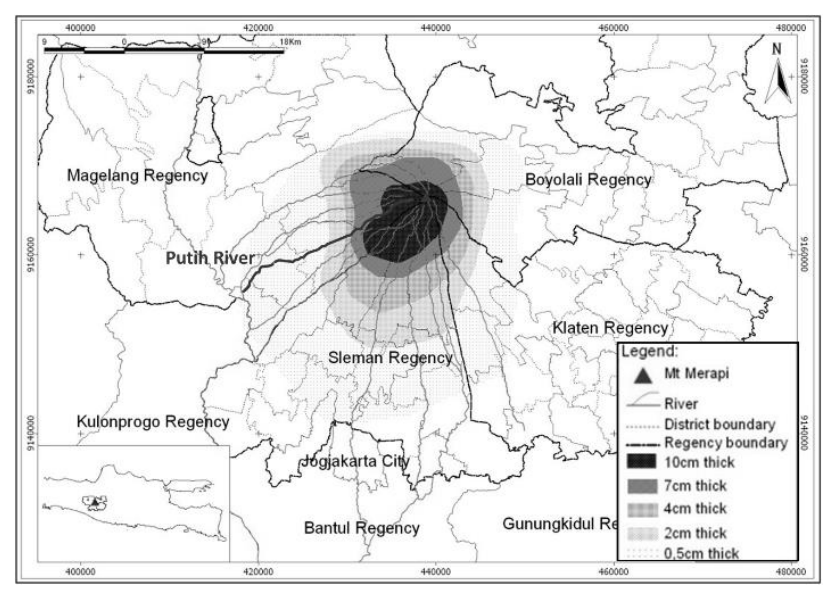

Fig. 2 Distribution of volcanic ash deposited by the November 3, 2010 eruption at Mt. Merapi. The map was created based on information provided by the Merapi Observatory and Technology Center (BPPTK).

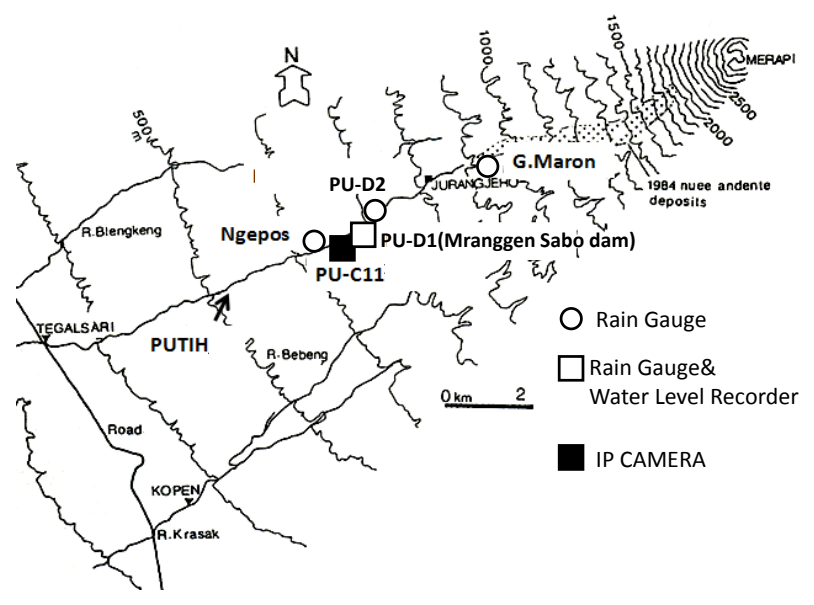

Fig. 3 Observation network in the Putih River basin.

internet protocol (IP) camera and a rain gauge that were installed after the eruption.

\section{METHODOLOGY}

The Putih River flows along the southwestern slope of Mt. Merapi. Figure 2 shows the distribution of volcanic ash deposited by the eruption. Large amounts of volcanic ash were deposited on the southwestern slope of Mt. Merapi during the eruption. In the upper reaches of the Putih River, the total depth of volcanic ash deposition during the 2010 eruption was estimated to be more than $10 \mathrm{~cm}$.

Figure 3 shows the observation network in the Putih River basin. Observations of debris flows and flash floods at the Mranggen sabo dam were started in November 1985 by the Volcanic Sabo Technical Centre (VSTC). The observation program was eventually taken over by the Sabo Technical Centre (STC) [Lavigne et. al, 2000a] and Balai Sabo

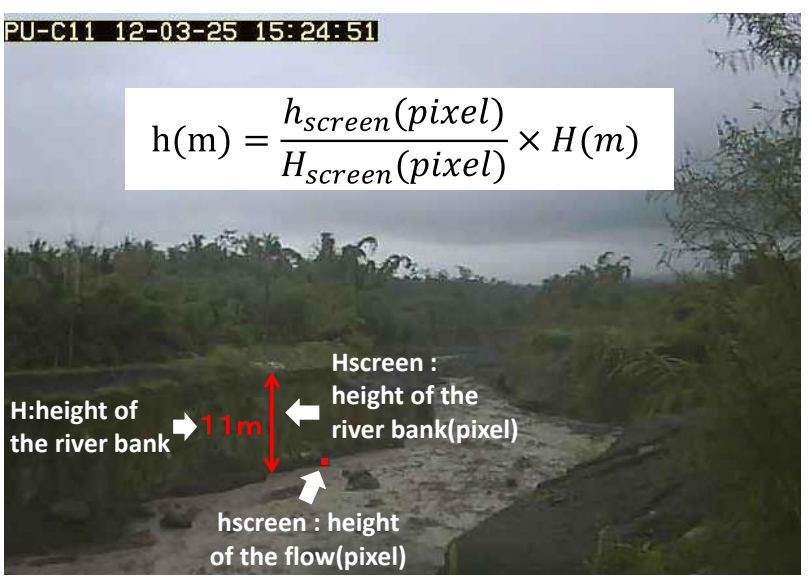

Fig. 4 Evaluation of flow height using still images acquired by the internet protocol (IP) camera.

(Experimental Station for Sabo). The Mranggen sabo dam was destroyed after the 2010 eruption of Mt. Merapi, and observations have been interrupted since then.

An IP camera was installed by Universitas Gadjah Mada (UGM) on the right bank of the Putih River near the PU-C11 sabo dam on January 2011. The camera captures still images of the river every 30 seconds and transmit them to the data server over internet. Still image capture resolution is $640 \times 480$. Because no illumination device for the camera was installed, no image was captured during the nighttime.

We counted the number of debris flows and flash floods that occurred during the daytime using the captured images. The water height and crosssectional area of debris flows and flash floods upstream of PU-C11 were evaluated using the captured images (Figure 4). Discharges associated with these events were calculated using Manning's formula. $\mathrm{n}=0.06$ [Koga and Agus, 1989] every 30 seconds. Total runoff and peak discharges of each events were calculated.

Observations of 10 min-rainfall data were started in November 1984 by VSTC and later collected by STC and Balai Sabo. The rain gauge was destroyed by the 2010 eruption. A new rain gauge was reinstalled in January 2012 by Balai Sabo.

After 1984 pyroclastic flows at Mt. Merapi that deposited pyroclastic material in the upper reaches of the Putih River basin, Jitousono et al. [1996] analyzed the characteristics of debris flows and flash floods using monitoring records of debris flows collected at the Mranggen sabo dam (PU-D1) and records of rainfall collected at the Gunung Maron monitoring station. They defined flow at the Mranggen sabo dam, which resulted in a peak discharge greater than $7 \mathrm{~m}^{3} / \mathrm{s}$, as flow in the form of a debris flow or flash flood. The following results 


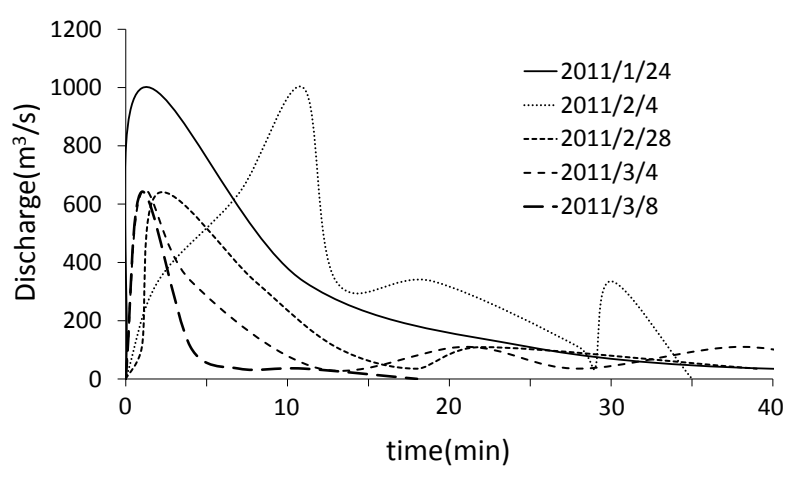

Fig. 5 Discharges of five debris flows or flash flood on the Putih river (January-March 2011), from captured images by the IP camera.

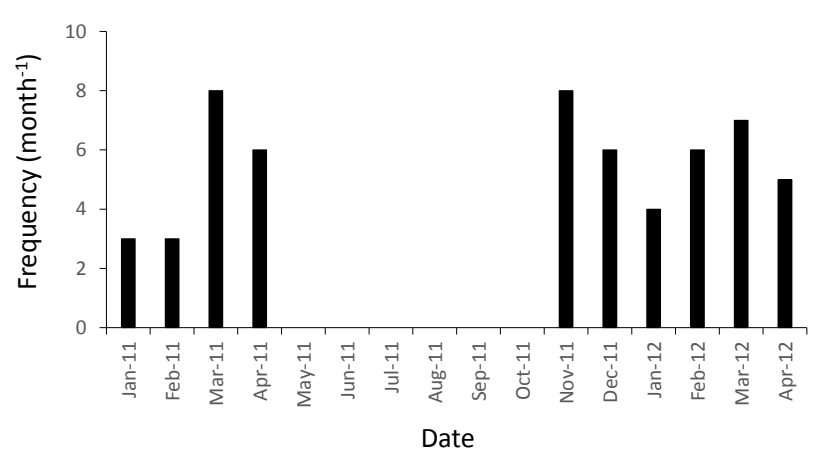

Fig. 6 Frequency of debris flow and flash flood occurrences.

were also obtained:

- Rainfall conditions that caused no debris flows or flash floods were different between the 4-year period after the 1984 pyroclastic flows and the years that followed.

- Rainfall intensity that caused no debris flows or flash floods was small soon after the pyroclastic flows. Then, the rainfall intensity increased over time.

- Large-scale debris flows occurred within a 4-year period after the 1984 pyroclastic flows. The magnitude of debris flows has decreased over time. During the 1990-1991 and 1991-1992 rainy season, few debris flows and flash floods occurred.

Unfortunately, rainfall records for the 2009-2010 rainy season have not yet been obtained. The year 2010 is notable because it represents the fourth year since a pyroclastic flow occurred (i.e., there was a pyroclastic flow event during the 2006 eruption at Mt. Merapi). According to a staff of Ministry of Public Works, frequency of debris flow and flash flood occurrences in the Putih River was low and the mass media, such as newspapers and televisions didn't report occurrence of debris flow and flash

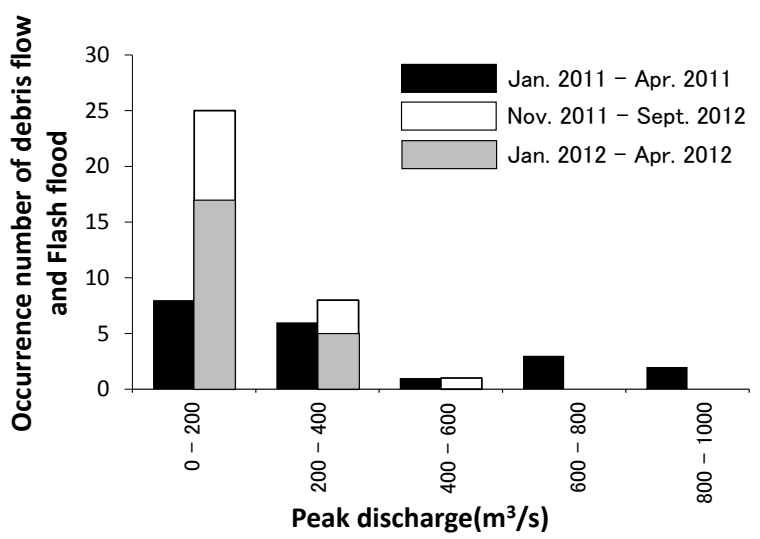

Fig. 7 Frequency distribution of the peak discharge for debris flows and flash floods at PU-C11 during January 23, 2011 to September 13, 2012.

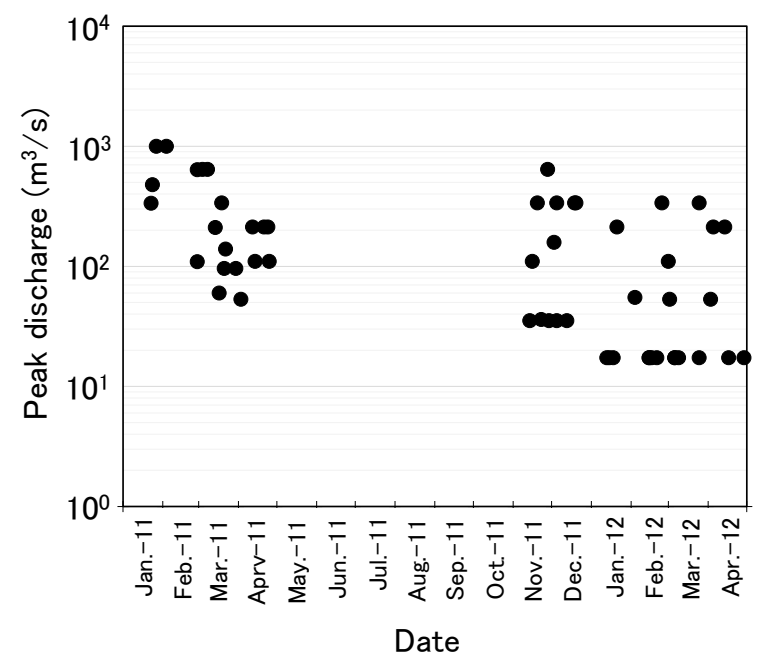

Fig. 8 Temporal changes in the peak discharge of debris flows and flash floods.

flood in the Putih River during the 2009-2010 rainy season. The number of debris flows and flash floods during the 2009-2010 rainy season was presumed to be as low as the number that occurred during the rainy season in the early 1990s. In this study, to clarify changes in the hydrological regime of the Putih River basin caused by the 2010 eruption, we analyzed water level records at the Mranggen sabo dam and rainfall records at the Gunung Maron observation station during 1991 and 1993.

\section{RESULTS AND DISCUSSION}

Debris flows and flash floods at Mt. Merapi were short events. The flows were usually characterized by one or two main surges. Peak discharge of a debris flow or flash flood generally occurred during its main surge, which usually followed the lahar front by a few minutes [Lavigne et al., 2000a]. Figure 5 shows five examples of discharges of debris flows and flash 


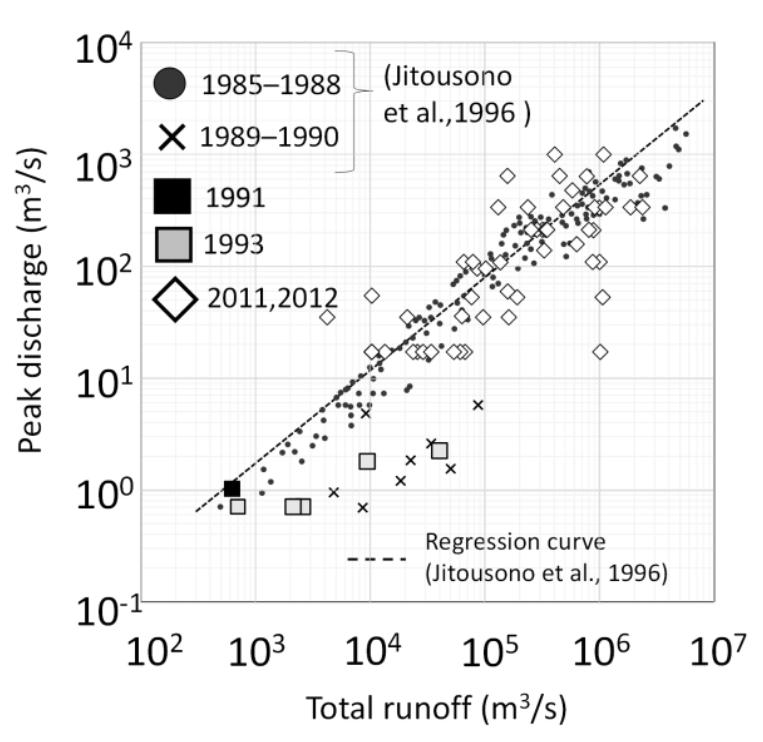

Fig. 9 Relationship between the peak discharge and the total runoff of debris flows and flash floods at the Putih River.

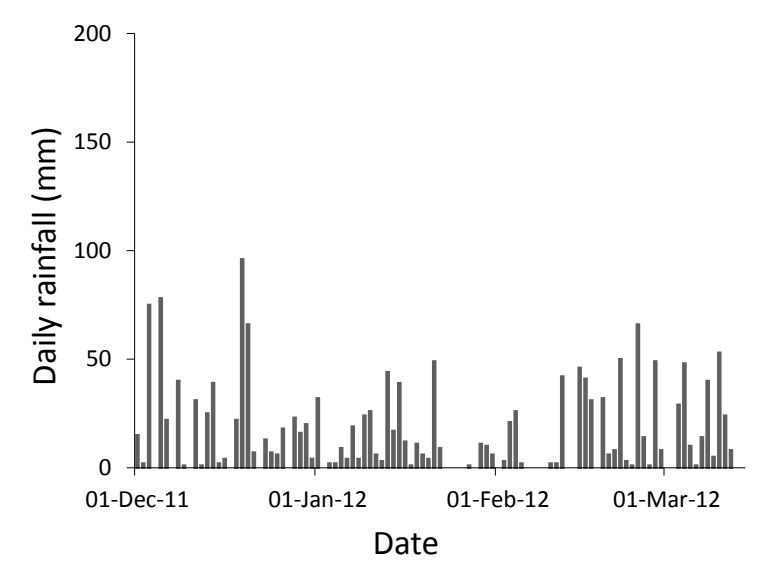

Fig. 10 Daily rainfall at the Gunung Maron monitoring station from December 2011 to March 2012.

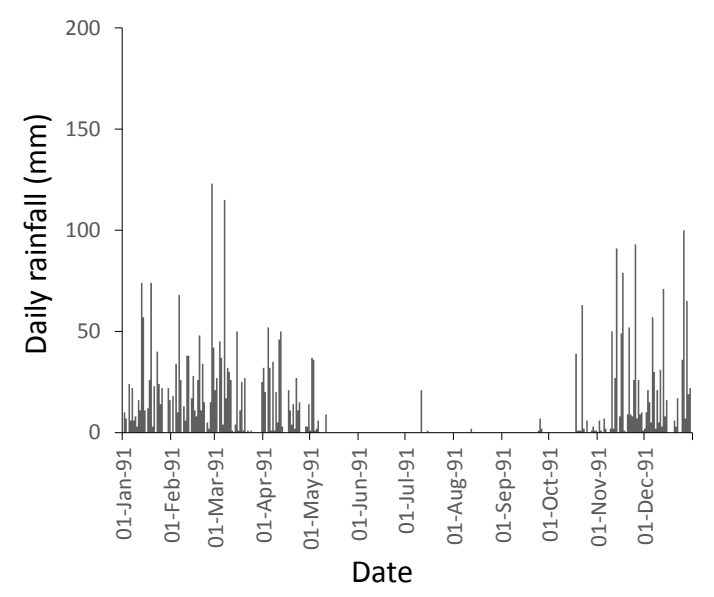

Fig. 11 Daily rainfall at the Gunung Maron monitoring station in 1991.

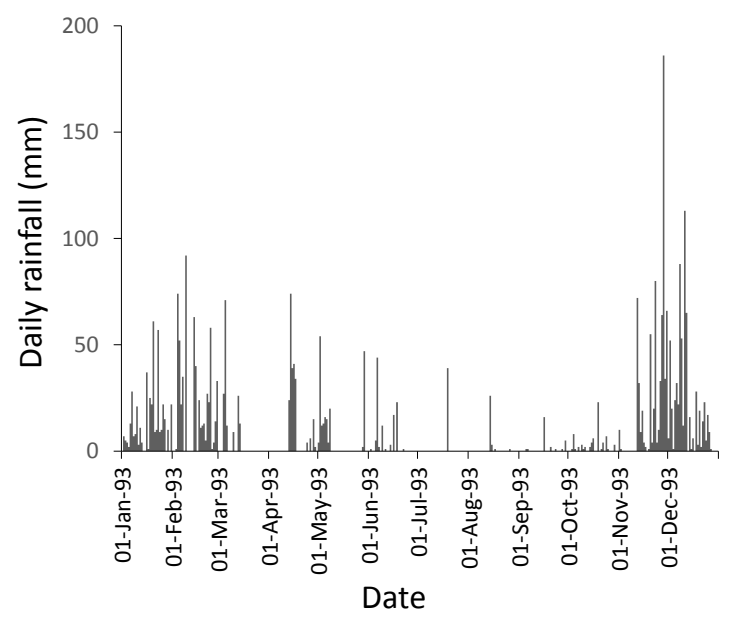

Fig. 12 Daily rainfall at the Gunung Maron monitoring station in 1993.

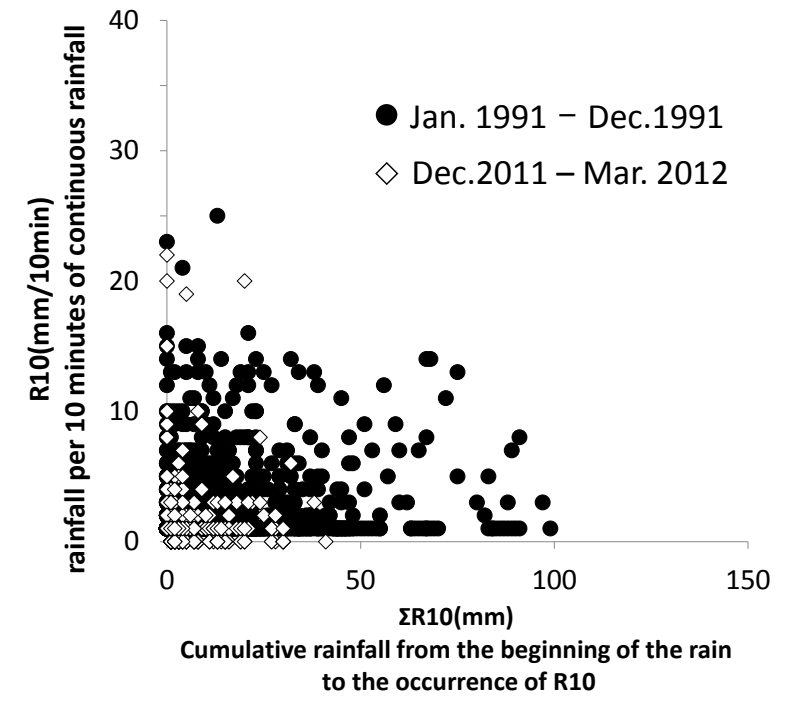

Fig. 13 Relationships between R10 and $\Sigma$ R10 (comparison of the 2011-2012 rainy season with 1991).

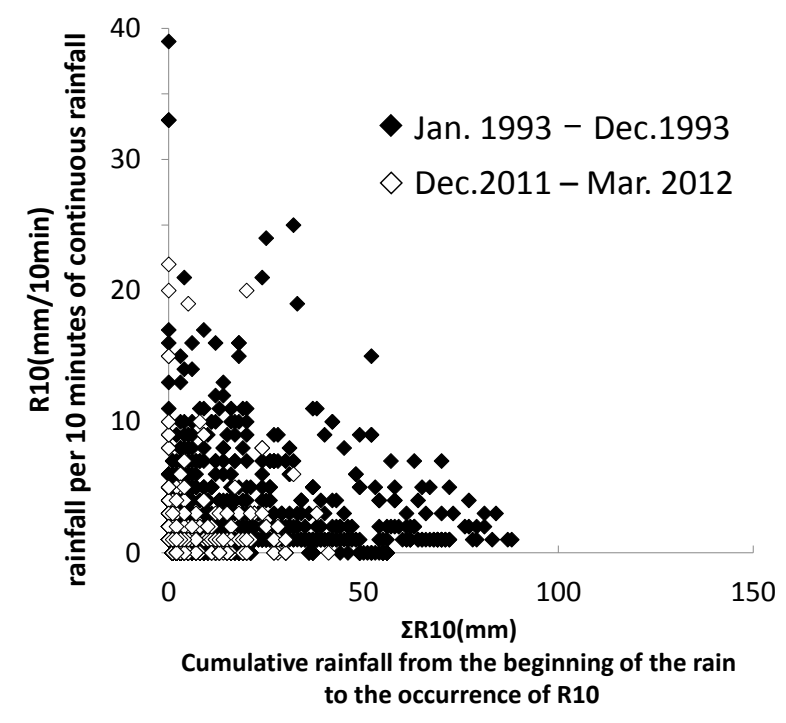

Fig. 14 Relationships between R10 and $\Sigma$ R10 (comparison of the 2011-2012 rainy season with 1993). 
flood in the Putih River evaluated using captured images by the IP camera installed at PU-C11. The hydrograph shapes for debris flows and flash floods shown in the Figure 5 are thought to be typical ones observed at Mt. Merapi. Though the capture rate of the IP camera is 30 seconds/image, it is thought that the peak discharges of debris flows and flash floods can be evaluated approximately using captured images.

A total of 56 debris flows and flash floods were observed during daylight hours at PU-C11 over a time-frame ranging from January 23, 2011 to September 13, 2012 (Figure 6). In contrast, only three debris flows and flash floods were observed in 1991 and 1993. Over a three month time period ranging from February to April, the number of debris flows and flash floods during the Jan.2011-Apr.2011 was similar to the number observed during the Nov.2011-Sept.2012. However, peak discharges of debris flows and flash floods during the Jan.2011Apr.2011 were smaller than those during the Nov.2011-Sept.2012 (Figure 7). During each rainy season, peak discharges tended to decrease over time. Dispersion of peak discharges of debris flows and flash floods during the Jan.2011-Apr.2011 were much greater than those during the Nov.2011Sept.2012 (Figure 8). It is thought that the decline of debris flows and flash floods is mainly caused by progressive loss of source pyroclastic debris, by the improvement in infiltration, and decrease in runoff, on hill slopes previously covered with pyroclastic tephra [Jitousono et al., 1996; Abdurachman et al., 2000]. It is also thought that decreased runoff is further aided by recovery of vegetation [Lavigne et al., 2000b].

Figure 9 shows the relationship between the peak discharge and the total runoff from debris flows and flash floods. The dotted line in Figure 9 depicts a regression curve used to fit data from debris flows and flash floods that occurred during 1985 to 1988 [Jitousono et al., 1996]. The relationship between the peak discharge and the total runoff of debris flows and flash floods after eruptions was highly linear from 1985 to 1988. From 1989 to 1990, the slope of the relationship decreased. The relationship between peak discharge and runoff during 1991 and 1993 showed a similar tendency to the relationship observed during 1989 to 1990 . Peak discharges and total runoff from debris flows and flash floods during 2011 and 2012 were much greater than those in 1991 and 1993.

Figures 10, 11, and 12 show daily rainfall data measured at the Gunung Maron monitoring station. Daily rainfall during the 2011-2012 rainy season tended to be less than the rainfall during 1991 and
1993 when the values were compared within the same month.

From the records of debris flows and flash floods observed at the PU-C11 sabo dam and Mranggen sabo dam, rainfall conditions were examined (Figures 13 and 14). In Figures 13 and 14, R10 is one of ten minutes rainfall data during continuous rainfall which caused no debris flows or flash floods and $\Sigma \mathrm{R} 10$ is the cumulative amount of ten minutes rainfall data from the beginning of the precipitation event to the occurrence of R10. During 2011-2012 rainy season, there were little information about debris flows and flash floods occurred during the nighttime because the IP camera was not available during the nighttime. As for 2011-2012 rainy season, the only rainfall data during the daytime was plotted in Figure 13 and 14.

The rainfall conditions for non-occurring debris flows and flash floods during the 2011-2012 rainy season were much less than those in 1991 and 1993. These results suggest that debris flows and flash floods occurred more easily in 2012 than in 1991 and 1993.

\section{CONCLUSIONS}

In this study, we analyzed the characteristics of debris flows and flash floods in the Putih River, an area where such events are common due to eruptions from nearby Mt. Merapi. Information was obtained from images captured by an IP camera at the PU-C11 sabo dam and a rain gauge at the Gunung Maron observation station. The results are summarized as follows:

- The magnitude of debris flows and flash floods during the 2011-2012 rainy season was smaller than during the 2010-2011 rainy season. In addition, the rainfall intensity that caused no debris flows and flash floods during the 20112012 rainy season was smaller than that during the early 1990s, when few debris flows and flash floods occurred.

- These results suggest that the hydrological regime of the catchment area was radically altered after the eruption. It is thought that the alteration of hydrological regime was caused mainly because thick deposited pyroclastic materials reduces permeability of ground surface and increases direct runoff rate(i.e. surface flow).

- A total of 56 debris flows and flash floods were observed during the daytime at PU-C11 over a time period ranging from January 23, 2011 to September 13, 2012.

- The number of debris flows and flash floods 
during the 2010-2011 rainy season was similar to the number observed during the 2011-2012 rainy season. However, peak discharges of debris flows and flash floods during the 2010-2011 rainy season were smaller than peak discharges during the 2011-2012 rainy season.

- The relationship between the peak discharge and the total runoff of debris flows and flash floods after the 2010 eruption was similar to the relationship observed during a 4-year period after the 1984 eruption.

We will continue monitoring debris flows and flash floods in the river basin to document the magnitude of these events and to determine if the hydrological regime will recover.

ACKNOWLEDGMENT: This work was supported by JSPS KAKENHI Grant Number 10303116.

\section{REFERENCES}

Abdurachman, E.K., Bourdier, J.L., Voight, B. (2000): Nue'es ardentes of 22 November 1994 at Merapi volcano, Indonesia. J. Volcanol. Geotherm. Res. Vol. 100, pp. 345-361.

De Bélizal, E., Lavigne, F., Sri Hadmoko, D., Degeai, J.-P., Aria Dipayan, G., Wahyu Mutaqion, B., Aris Marfai, M., Coquet, M., Le Mauff, B., Robin, A.-K., Vidal, C., Cholik, N., Aisyah, N. (2013): Rain-triggered lahars following the 2010 eruption of Merapi volcano, Indonesia: A major risk, Journal of Volcanology and Geothermal Research, Vol. 261, pp. 330-347.
Gonda, Y., Hotta, N., Legono, D., Santosa, U.B. (2012): Study on multimodal sediment disaster after the 2010 eruption of Mt. Merapi in Indonesia, Report of a study on sabo and landslide prevention technology, Sabo and Landslide Technical Center, Tokyo, pp. 147-166 (In Japanese).

Jitousono, T., Shimokawa, E., Tsuchiya, S. (1996): Debris-flow following the 1984 eruption with pyroclastic flows in Merapi volcano, Indonesia, Journal of the Japan Society of Erosion Control Engineering, Vol. 48, No. Special Issue, pp. 109-116.

Koga, S. and Agus, S. (1989): Provisional hydrological study on some data obtained by short range radar raingauge, Proceedings of International Symposium on Erosion and Volcanic Debris Flow Technology, Yogyakarta, Indonesia, July-August 1989, Vol. 15, pp. 1-26.

Lavigne, F., Thouret, J.-C., Voight, B., Young, K., LaHusen, R., Marse, J., Suwa, H., Sumaryono, A., Sayudi, D. S., Dejean, M. (2000a): Instrumental lahar monitoring at Merapi Volcano, Central Java, Indonesia, Journal of Volcanology and Geothermal Research, Vol. 100, pp. 457-478.

Lavigne, F., Thouret, J.-C., Voight, B., Suwa, H., Sumaryono, A. (2000b): Lahars at Merapi Volcano, Central Java: an overview, Journal of Volcanology and Geothermal Research, Vol. 100, pp. 423-456.

National Disaster Management Agency (BNPB), Indonesia (2011): BNPB report released on April 29, 2011, http://www.bnpb.go.id/website/asp/berita_list.asp?id=434 [accessed on May 1, 2011].

Received: 30 July, 2013

Accepted: 22 June, 2014 